Interdisciplinary Studies of Complex Systems

No. 15 (2019) 67-87

(C) Т. Костирко, I. Бондар, Т. Корольова, М. Жигалкіна

https://doi.org/10.31392/iscs.2019.15.067

\title{
ДОСЛІДЖЕННЯ РЕЗУЛЬТАТИВНОСТІ НАУКОВОЇ ТА НАУКОВО-МЕТОДИЧНОЇ ДІЯЛЬНОСТІ НАЦІОНАЛЬНОГО УНІВЕРСИТЕТУ КОРАБЛЕБУДУВАННЯ ІМЕНІ АДМІРАЛА МАКАРОВА У СФЕРІ СУДНОБУДУВАННЯ ТА СУМІЖНИХ ГАЛУЗЯХ
}

\author{
Тамара Костирко ${ }^{1,2}$ Ірина Бондар ${ }^{1,3}$, \\ Тетяна Корольова ${ }^{1,4}$, Марина Жигалкіна ${ }^{1,5}$
}

Ключові слова: бібліометрія, наукометричні бази даних, показники пу-

блікаційної активності, наукометричний аналіз.

\section{SCIENTIFIC ACTIVITY EFFECTIVENESS OF ADMIRAL MAKAROV NATIONAL UNIVERSITY OF SHIPBUILDING IN THE FIELD OF SHIPBUILDING AND RELATED INDUSTRIES RESEARCH}

\author{
Tamara Kostyrko, Iryna Bondar, \\ Tetyana Korolova, Maryna Zhyhalkina
}

\begin{abstract}
Keywords: bibliometry, scientometric databases, indexes of publishing acti-
\end{abstract} vity, scientometric analysis.

The object of the research is the publication activity of the scientific and pedagogical staff of admiral Makarov National University of Shipbuilding (NUOS).

The source of the data used in the study are the scientometric databases Scopus and Web of Science.

The purpose of the research: to trace the dynamics of the publication activity and effectiveness of scientific activity of the scientific and pedagogical staff of the University for the last five years (2013-2017).

We analyzed:

1. Dynamics of indicators of the publication activity of the NUOS on the basis of general indicators of the organization's public activity for the period

\footnotetext{
${ }^{1}$ Національний університет кораблебудування імені адмірала Макарова

2 tamara.kostyrko@nuos.edu.ua, https://orcid.org/0000-0002-4175-9975.

3 iryna.bondar@nuos.edu.ua, https://orcid.org/0000-0002-1011-2079.

4 tetyana.korolova@nuos.edu.ua, https://orcid.org/0000-0001-8066-6141.

${ }^{5}$ maryna.kostyrko@nuos.edu.ua, https://orcid.org/0000-0002-2366-6927.
} 
2013-2017. For this purpose, a general university profile was used in the Scopus and Web of Science databases.

2. Analysis of publications of scientific and pedagogical staff of NUOS in each of the science-based databases for the period 2013-2017.

3. The publications (journals, conference materials, sections of books) were analyzed, in which scientific and pedagogical employees of the NUOS were published for the period 2013-2017.

4. Scientometric analysis of publications of scientific and pedagogical employees of NUOS in science branches in Scopus and Web of Science databases was conducted.

5. Scientometric analysis of scientific and pedagogical employees of NUOS in the engineering industry was conducted.

6. 160 questionnaires were analyzed, within the framework of sociological research among scientific and pedagogical staff of the NUOS with the purpose of analyzing scientometric indicator of the scientist; attitudes toward the sciencebased databases that they favor; Identification of problems arising in the process of integration into the scientific world community.

\section{Conclusions}

During the 2013-2017 period there was a positive growth dynamics in the number of publications and productivity of the NUOS authors. Since 2015, the publication activity of the University authors has increased noticeably. One of the reasons for this is the implementation start of the Cabinet of Ministers of Ukraine Decree, dated December 30, 2015, No. 1187 (Kyiv) "On Approval of Licensing Conditions for the Educational Activities of Educational Institutions", another important factor - the increasing awareness of employees about ways to evaluate their work performance. This was facilitated by the activities on the formation of an information culture conducted by the Scientific Library of the NUOS. Most of the publications refer to research in the technical sciences. This is due to the traditionally strong areas of scientific research at the university.

Thanks to the conducted research, it became possible to determine the priority directions of scientific developments, as well as to identify scientists scientific leaders of the university. The results of our analysis of the publication activity of scientific and pedagogical employees of the NUOS are very important. They can be used as a tool to detect weaknesses in the research activities of the university and to find ways to improve it.

In the future, we believe that the results of the research will be applied in the analysis of the scientific and economic activities of the Mykolayiv region, namely, with the revival of the shipbuilding industry in Ukraine.

На сучасному етапі розвитку науки перспективність і затребуваність бібліометричних досліджень обумовлені комплексом факторів.

На основі бібліометричних показників розробляють системи оцінки наукових досліджень, прогнозують розвиток науки, вибудовують наукову 
політику, приймають управлінські рішення [1]. Основна мета ефективної системи формальної оцінки - формування стимулів для виробництва, відтворення і тиражування наукових знань, розробки стратегії і практичного підвищення продуктивності науково-дослідницької діяльності (НДД) в якісному і кількісному вираженні [2].

Біометричні методи також відіграють все більшу роль у рейтингу науково-дослідних підрозділів та установ [3]. Університети завжди були невичерпним джерелом кадрів - готували майбутніх молодих дослідників для наукових інститутів. А заклади вищої освіти (ЗВО), в свою чергу, зацікавлені у фахових наукових компетенціях і обладнанні, які завжди були в академічному середовищі [4].

Одним з найважливіших показників роботи ЗВО є його наукові досягнення. Сучасна наука організована таким чином, що ключовим результатом діяльності вченого або групи вчених є стаття в професійному журналі [5], і все частіше інтерес звертається до «вихідного параметру» кількості цитувань. Показник цитування публікацій вченого або організації відображає значимість проведеного дослідження, будучи стимулом підвищення якості майбутніх публікацій [6].

Предметом наукометричних досліджень на рівні регіону стає діяльність ЗВО. Тобто, наукометричні розробки стають одним з інструментів комплексного прогнозування інноваційної складової соціально-економічного розвитку регіону [1].

Національний університет кораблебудування імені адмірала Макарова $(\mathrm{HУK})$ - єдиний в Україні унікальний вищий навчальний заклад, який здійснює підготовку фахівців для суднобудівного, машинобудівного, енергетичного, морегосподарського комплексів України та інших країн світу за міжнародними нормами і вимогами.

Навчально-виховний процес у НУК забезпечують 57 кафедр, на яких працюють 539 викладачів.

З 2012 року Науковою бібліотекою НУК розпочато новий вид діяльності - інформаційна аналітика, як інструментарій моніторингу світового наукового інформаційного потоку, аналіз рівня цитування вчених та індексу впливу періодичних видань НУК в міжнародному інформаційному просторі, їх просування до наукометричних індексів основних галузевих та міжнародних баз даних.

Одним із напрямків роботи Наукової бібліотеки стало виявлення наукової активності НУК в цілому та публікаційної активності вченого за допомогою наукометричних та бібліометричних досліджень.

Останнім часом у світовій пресі опублікована велика кількість бібліометричних аналізів досліджень $[7,8,9,10]$, що базуються на використанні двох баз даних: Web of Science i Scopus. Слід відмітити, що кількісні показники цих наукометричних баз даних усе активніше використовуються зарубіжними країнами для визначення та оцінювання ефективності діяльності як окремого науковця, колективу чи організації, так і перспективних напрямів розвитку науки, їх фінансування тощо.

У 2018 році відповідно до доручення Міністерства освіти і науки України Державна науково-технічна бібліотека України оголосила проведення конкурсу на кращу наукову роботу (далі Конкурс) з теоретичних та при- 
кладних аспектів порівняльного аналізу діяльності дослідників, наукових колективів та наукових установ України. Конкурс було проведено з метою визначення експертного середовища та залучення експертів до обговорення проблем, що стосуються питань оцінки національної науки.

Наукова бібліотека НУК для участі у Конкурсі підготувала «Дослідження результативності наукової та науково-методичної діяльності Національного університету кораблебудування імені адмірала Макарова у сфері суднобудування та суміжних галузях».

Об‘ $є$ ктом дослідження $є$ публікаційна активність науково-педагогічних працівників (НПП) НУК. Джерелом даних, використаних у дослідженні, $є$ авторитетні наукометричні бази даних (БД) Scopus $i$ Web of Science Core Collection (WoS) за період з 2013 по 2017 рр. станом на 01.04.2018 p.

Мета дослідження: відстежити динаміку публікаційної активності та результативності наукової діяльності НПП університету за період 20132017 pp.

Продуктивність дослідників, а також цінність та якість наукових публікацій розглядаються як властивості, що вказують на ефективність дослідницької діяльності організації [11]. Вивчення в цілому було спрямоване на оцінку ефективності наукових досліджень НУК.

Згідно результатів конкурсу МОН України, проведеного у серпні 2017 р., Національний університет кораблебудування імені адмірала Макарова отримав доступ до наукометричної БД Scopus за кошти держбюджету.

3 моменту отримання доступу проведено роботу з об'єднання ідентифікаторів організації НУК та створення єдиного профіля університету у БД Scopus та WoS. У офіційному профілі HУK у БД Scopus (Admiral Makarov National University of Shipbuilding) на 01.04.2018 р. представлено 194 автори, 250 документів. У офіційному профілі HУK у БД WoS представлено 246 авторів та 144 документи. Робота з наповнення єдиних профілів НУК продовжується.

При аналізі ми намагалися врахувати важливу для нашого університету обставину - неодноразову зміну його назви. Знайдено 54 потенційних збіги назв університету та назв філій НУК у Первомайську, Херсоні, Феодосії (до 2014 р.). Крім того, слід було взяти до уваги і той факт, що автори використовують різне написання назви університету англійською мовою. Зазначені вище цифри отримані з урахуванням цих факторів [12].

Дані дослідження представлено у звіті, додатку з таблицями та підтверджуються вибірками із наукометричних БД Scopus i WoS, що представлені у додатках у форматі *.xls.

Загальні показники публікаційної активності НУК імені адмірала Макарова наведено у табл. 1.

Таблиця 1 свідчить, що автори-НПП НУК більшу частину своїх наукових робіт публікують у вітчизняних виданнях (94,8\%). Решта $5,2 \%$ припадають на зарубіжні видання. Тільки $3,1 \%$ від загальної кількості публікацій припадає на наукометричні БД Scopus i WoS. Сумарна кількість цитувань публікацій у наукометричних БД Scopus i WoS в організації 735, кількість авторів - 550 (середнє арифметичне за 2013-2017рр.), сумарний індекс Хірша у наукометричних БД Scopus i WoS - 16. Середня кількість публікацій у наукометричних БД із розрахунку на 1 автора (продуктивність) - 0,4; середня кількість цитувань у наукометричних БД із розрахунку на 1 публікацію - 1,3. 
Таблиця 1. Загальні показники публікаційної активності НУК (за 2013-2017 рр.)

\begin{tabular}{|c|c|}
\hline Показник & Кількість \\
\hline $\begin{array}{l}\text { Загальна кількість публікацій установи (за да- } \\
\text { ними річних звітів НУК) }\end{array}$ & $7325(100 \%)$ \\
\hline в українських виданнях & $6944(94,8 \%)$ \\
\hline у т.ч. у фахових журналах & $2442(35,2 \%)$ \\
\hline у закордонних виданнях & $381(5,2 \%)$ \\
\hline у т.ч. у наукометричних БД Scopus i WoS & $225(3,1 \%)$ \\
\hline $\begin{array}{l}\text { Кількість авторів установи (за даними річних } \\
\text { звітів НУК) }\end{array}$ & 550 (середнє арифм) \\
\hline $\begin{array}{l}\text { Сумарна кількість цитувань публікацій у нау- } \\
\text { кометричних БД Scopus i WoS в організації }\end{array}$ & 735 \\
\hline $\begin{array}{l}\text { Продуктивність авторів (середня кількість пу- } \\
\text { блікацій із розрахунку на } 1 \text { автора) }\end{array}$ & 13,3 \\
\hline $\begin{array}{l}\text { Продуктивність авторів у наукометричних БД } \\
\text { (середня кількість публікацій у наукометри- } \\
\text { чних БД із розрахунку на } 1 \text { автора) }\end{array}$ & 0,4 \\
\hline $\begin{array}{l}\text { Середня кількість цитувань у наукометричних } \\
\text { БД у рахунку на } 1 \text { публікацію }\end{array}$ & 1,3 \\
\hline $\begin{array}{l}\text { Сумарний індекс Хірша у наукометричних БД } \\
\text { Scopus i WoS }\end{array}$ & 16 \\
\hline у т.ч. БД Scopus & 9 \\
\hline БД WoS & 7 \\
\hline $\begin{array}{l}\text { Позиція у Консолідованому рейтингу } \\
\text { УКраїни } 2017 \text { року* }\end{array}$ & 75 \\
\hline $\begin{array}{l}\text { Позиція у Рейтингу університетів за показни- } \\
\text { ками Scopus на 01.04. } 2018 \text { р.** }\end{array}$ & 53 \\
\hline
\end{tabular}

*За даними підсумкової таблиці консолідованого рейтингу вищих навчальних закладів України на сайті Освіта.ua http://ru.osvita.ua/vnz/rating/ $51741 /)$.

**За даними рейтингу українських закладів вищої освіти, зробленого на підставі наукометричного моніторингу суб'єктів науково-видавничої діяльності України, за показниками бази даних SciVerse Scopus (видавнича служба «УРАН», на замовлення сайту Освіта.ua http://osvita.ua/vnz/rating/ $60539 /)$.

Частка публікацій авторів-НПП НУК у фахових журналах складає 35,2 \% від загальної кількості публікацій в українських виданнях та $33,3 \%$ від загального публікаційного потоку установи.

Аналізуючи ці дані, можна зробити висновок, що стійка прив'язка до публікацій в «своїх» журналах гальмує процес розвитку міжнародної публікаційної активності НУК і України в цілому. I, навпаки, якщо активніше публікуватися в міжнародних журналах, у національній публікаційній активності з'являються можливості для зростання. Як наслідок не високі позиції університету у впливових рейтингах: позиція НУК у Консолідованому рейтингу ВНЗ України 2017 р. за даними підсумкової таблиці консо- 
лідованого рейтингу закладів вищої освіти України на сайті Освіта.uа - 75 (з 288). Позиція НУК у Рейтингу університетів за показниками Scopus за даними рейтингу українських закладів вищої освіти, зробленого на підставі наукометричного моніторингу суб'єктів науково-видавничої діяльності України, за показниками бази даних Scopus на 01.04. 2018 р. - 53 (зі 162).

У таблиці 2 представлено динаміку показників публікаційної активності НПП НУК у наукометричних БД за 2013-2017 pp. Ми бачимо, що кількість публікацій у наукометричних БД Scopus i WoS за 5 років збільшилася майже в 4 рази. За період 2013-2017 pp. 225 документів увійшли до наукометричних БД, що складає $57 \%$ від загальної кількості документів (394). Кількість цитувань публікацій у наукометричних БД Scopus i БД WoS зросла майже в 6 разів (з 44 у 2013 р. до 254 у 2017 р.). Від сумарної кількості цитувань публікацій у наукометричних БД (735) кількість цитувань у БД Scopus складає - 465 (63,3\%), а у БД WoS - $270(36,7 \%)$. Середня кількість цитувань у БД із розрахунку на 1 публікацію зросла майже в 2 рази - з 1,9 у 2013 р. до 2,9 у 2017 р.

Більше ніж в 4 рази зросла продуктивність авторів у наукометричних БД (кількість публікації із розрахунку на 1 автора) - з 0,04 у 2013 р. до 0,17 у 2017 p.

Частка високоцитуємих публікацій $\geq 5$ у наукометричних БД (\%) зменшилася 3 43,5\% до 14,2\% від загальної кількості публікацій, а частка нецитуємих публікацій у наукометричних БД збільшується 3 30,4\% до $58,7 \%$. Це пов'язано з тим, що цитування публікацій в різних галузях знань має свої особливості. Відомо, що найбільша кількість посилань на публікації доводиться на певні періоди. Найбільший приріст посилань за досліджуваний часовий інтервал відбувається з другого по четвертий роки після виходу публікацій. Крім того, спостерігається значне підвищення порога середнього цитування на публікації в кожному наступному за попереднім часовим інтервалом, що дозволяє говорити про підвищення попиту на публікації наших вчених. Підтвердженням можуть служити дані про середні частки публікацій, що не отримали жодного посилання в документопотоках за заданим часовим інтервалом [13].

В цілому динаміка показників публікаційної активності НУК свідчить про підвищення якості науково-інформаційної діяльності (НІД). Однак, у установи є резерви для її підвищення, зокрема для збільшення долі високоцитуємих публікацій та зниження частки нецитуємих публікацій НПП.

Одна з найважливіших характеристик загального рівня розвитку науки в країні - кількість наукових статей, опублікованих в найбільших авторитетних журналах. Це пов'язано з тим, що рівень опублікованих робіт оцінюють у відповідності зі значимістю журналу. Публікації в рецензованих міжнародних журналах та їх цитованість входять в число ключових показників, орієнтуючи ЗВО на збільшення кількості публікацій як в короткостроковій, так і в довгостроковій перспективі [14].

У деяких наукових дисциплінах не лише журнали відіграють роль найважливішого каналу наукової комунікації (для гуманітарних наук - це наукові монографії, а для природничих та IT наук - матеріали конференцій, які посідають чільне місце) [15]. 
Таблиця 2. Динаміка показників публікаційної активності у наукометричних БД Scopus i WoS HПП HУК за період 2013-2017 pp.

\begin{tabular}{|c|c|c|c|c|c|c|c|}
\hline Показник & 2013 & 2014 & 2015 & 2016 & 2017 & $\begin{array}{c}2013- \\
2017\end{array}$ & $\begin{array}{c}\text { Всього } \\
\text { на } \\
1.04 .2018\end{array}$ \\
\hline $\begin{array}{l}\text { Кількість авторів-НПП } \\
\text { НУК (за даними річних } \\
\text { звітів НУК) }\end{array}$ & 590 & 548 & 548 & 534 & 534 & 550 & 539 \\
\hline $\begin{array}{l}\text { Кількість публікацій за } \\
\text { рік (за даними річних } \\
\text { звітів НУК) }\end{array}$ & 1430 & 1390 & 1493 & 1562 & 1450 & $\begin{array}{c}7325 \\
(100 \%)\end{array}$ & - \\
\hline $\begin{array}{l}\text { у т.ч. наукометричних } \\
\text { БД Scopus i WoS }\end{array}$ & 23 & 24 & 43 & 46 & 87 & $\begin{array}{c}225 \\
(57 \%)\end{array}$ & $\begin{array}{c}394 \\
(100 \%)\end{array}$ \\
\hline у т.ч. у БД Scopus & 18 & 19 & 21 & 28 & 55 & $\begin{array}{c}141 \\
(62,7 \%)\end{array}$ & $\begin{array}{c}250 \\
(63,5 \%) \\
\end{array}$ \\
\hline у БД WoS & 5 & 5 & 22 & 18 & 34 & $\begin{array}{c}84 \\
(37,7 \%)\end{array}$ & $\begin{array}{c}144 \\
(36,5 \%)\end{array}$ \\
\hline $\begin{array}{l}\text { Сумарна } \\
\text { цитувань } \quad \text { публікість } \\
\text { у наукометричних БД } \\
\text { Scopus і БД WoS }\end{array}$ & 44 & 94 & 152 & 191 & 254 & $\begin{array}{c}735 \\
(100 \%)\end{array}$ & $\begin{array}{c}900 \\
(100 \%)\end{array}$ \\
\hline у т.ч. у БД Scopus & 29 & 54 & 92 & 123 & 167 & $\begin{array}{c}465 \\
(63,3 \%)\end{array}$ & $\begin{array}{c}590 \\
(65,6 \%)\end{array}$ \\
\hline у БД WoS & 15 & 40 & 60 & 68 & 87 & $\begin{array}{l}270 \\
(36,7 \%)\end{array}$ & $\begin{array}{c}310 \\
(34,4 \%)\end{array}$ \\
\hline $\begin{array}{l}\text { Продуктивність авторів } \\
\text { у наукометричних БД } \\
\text { (кількість публікації із } \\
\text { розрахунку на } 1 \text { авто- } \\
\text { ра) }\end{array}$ & 0,04 & 0,04 & 0,08 & 0,09 & 0,17 & 0,4 & 0,73 \\
\hline $\begin{array}{l}\text { Середня кількість ци- } \\
\text { тувань у наукометри- } \\
\text { чних БД із розрахунку } \\
\text { на } 1 \text { публікацію }\end{array}$ & 1,9 & 3,9 & 3,5 & 4,1 & 2,9 & 3,3 & 2,3 \\
\hline $\begin{array}{l}\text { Кількість публікацій, } \\
\text { що були процитовані } \\
\geq 5 \text { БД Scopus }\end{array}$ & 7 & 8 & 4 & 1 & 1 & 21 & 45 \\
\hline $\begin{array}{l}\text { Кількість публікацій, } \\
\text { що були процитовані } \\
\geq 5 \text { БД WoS }\end{array}$ & 3 & 5 & 2 & - & 1 & 11 & 19 \\
\hline $\begin{array}{l}\text { Загальна кількість } \\
\text { публікацій, що були } \\
\text { процитовані } \geq 5 \text { (БД } \\
\text { Scopus, БД WoS) }\end{array}$ & 10 & 13 & 6 & 1 & 2 & 32 & 64 \\
\hline $\begin{array}{l}\text { Частка високоцитуємих } \\
\text { публікацій } \geq 5 \text { у науко- } \\
\text { метричних БД (\%) }\end{array}$ & 43,5 & 53,8 & 14 & 2,2 & 2,2 & 14,2 & 16 \\
\hline $\begin{array}{l}\text { Кількість публікацій, } \\
\text { що не були процитовані } \\
\text { БД Scopus }\end{array}$ & 6 & 7 & 10 & 14 & 41 & 78 & 138 \\
\hline $\begin{array}{l}\text { Кількість публікацій, } \\
\text { що не були процитовані } \\
\text { БД WoS }\end{array}$ & 1 & - & 11 & 11 & 31 & 54 & 91 \\
\hline $\begin{array}{l}\text { Загальна кількість } \\
\text { публікацій, що не } \\
\text { були процитовані (БД } \\
\text { Scopus, БД WoS) }\end{array}$ & 7 & 7 & 21 & 25 & 72 & 132 & 229 \\
\hline $\begin{array}{l}\text { Частка нецитуємих пу- } \\
\text { блікацій у наукометри- } \\
\text { чних БД (\%) }\end{array}$ & 30,4 & 29,2 & 48,8 & 54,3 & 80,9 & 58,7 & 60,2 \\
\hline
\end{tabular}


Щоб проаналізувати публікації НПП НУК з цієї точки зору по БД Scopus i WoS, складена вибірка наукових журналів, у яких публікувалися наші вчені. Розподіл публікацій за типами документів (наукова стаття, матеріали конференцій та ін.) у БД НПП НУК представлено у таблиці 3.

Таблиця 3. Розподіл публікацій за типами документів (наукова стаття, матеріали конференцій та ін.) у БД Scopus i WoS HПП HУK

\begin{tabular}{|c|c|c|c|c|c|c|c|c|c|c|c|c|c|c|}
\hline \multirow[t]{2}{*}{$\begin{array}{c}\text { Тип } \\
\text { документа }\end{array}$} & \multicolumn{2}{|c|}{2013} & \multicolumn{2}{|c|}{2014} & \multicolumn{2}{|c|}{2015} & \multicolumn{2}{|c|}{2016} & \multicolumn{2}{|c|}{2017} & \multicolumn{2}{|c|}{$\begin{array}{c}2013- \\
2017\end{array}$} & \multicolumn{2}{|c|}{ Всього } \\
\hline & $\begin{array}{l}\text { Sco- } \\
\text { pus }\end{array}$ & WoS & $\begin{array}{l}\text { Sco- } \\
\text { pus }\end{array}$ & WoS & $\begin{array}{l}\text { Sco- } \\
\text { pus }\end{array}$ & Wos & $\begin{array}{l}\text { Sco- } \\
\text { pus }\end{array}$ & Wos & $\begin{array}{l}\text { Sco- } \\
\text { pus }\end{array}$ & WoS & $\begin{array}{l}\text { Sco- } \\
\text { pus }\end{array}$ & Wos & $\begin{array}{l}\text { Sco- } \\
\text { pus }\end{array}$ & Wos \\
\hline Article & 14 & 5 & 18 & 5 & 14 & 9 & 21 & 16 & 38 & 21 & 105 & 58 & 180 & 108 \\
\hline $\begin{array}{l}\text { Conference } \\
\text { Paper } \\
\text { (Proceedings } \\
\text { Paper) }\end{array}$ & 4 & - & 1 & - & 7 & 8 & 6 & 6 & 15 & 13 & 33 & 27 & 62 & 37 \\
\hline Note & - & - & - & - & - & - & - & - & - & - & - & - & 4 & - \\
\hline $\begin{array}{l}\text { Book } \\
\text { Chapter }\end{array}$ & - & - & - & - & - & - & - & 1 & 2 & 2 & 2 & 3 & 3 & 3 \\
\hline $\begin{array}{l}\text { Article in } \\
\text { Press }\end{array}$ & - & - & - & - & - & - & - & - & - & - & - & - & 1 & \\
\hline Review & - & - & - & - & - & 1 & 1 & - & - & - & 1 & 1 & 1 & 1 \\
\hline
\end{tabular}

У БД Scopus за період 2013-2017 рр. НУК представлено 141 документом у 60 виданнях. Серед них 105 статей у журналах, 33 документи у матеріалах конференцій, 2 розділи книг та 1 огляд. Серед 44 журналів 15 журналів відкритого доступу.

Найбільш активно автори публікували свої роботи у 2017 р. (54), 2016 р. (28) та 2015 р. (21). За 2013-2017 pp. h-index НУК складає 9, сумарна кількість цитувань - 465.

Географія видань різноманітна: Україна - 11 (22,2\%), США - 5 (11\%), Велика Британія - 4 (9\%), РФ - 4 (9\%), Індія, Німеччина, Нідерланди, Хорватія, Китай по $2(4,4 \%)$ та ін.

Українські видання у БД Scopus представлено 11 журналами та 6 матеріалами конференцій.

У БД Scopus статті у журналах найбільш активно публікувалися у 2017 р. (38), 2016 р. (21) та 2014 р. (18) (рис. 1.).

Основні галузі знань, за якими було надруковано найбільше статей представлено на рис. 2.: Engineering (43), Physics and Astronomy (29), Mathematics (23), Energy (20), Computer Science (19), Business, Management and Accounting (15), Economics, Econometrics and Finance (12), Materials Science (10), Earth and Planetary Sciences (8), Chemistry (7).

Серед авторів найбільш активними були: Ushcats, M.V. (13), Moonesun, M. (10), Serbin, S.I. (10), Korol, Y.M. (7), Brazhko, A. (4), Goncharova, N.A. (4), Washchilenko, N.V. (4).

У БД Scopus найбільш цитовані статті надруковано у журналах: Education + Training (27); Journal of Chemical Physics (17); Physical Review E - Statistical, Nonlinear, and Soft Matter Physics (14); IEEE Transactions on Plasma Science (14); IEEE Transactions on Plasma Science (12); Indian Journal of Marine Sciences (9). 


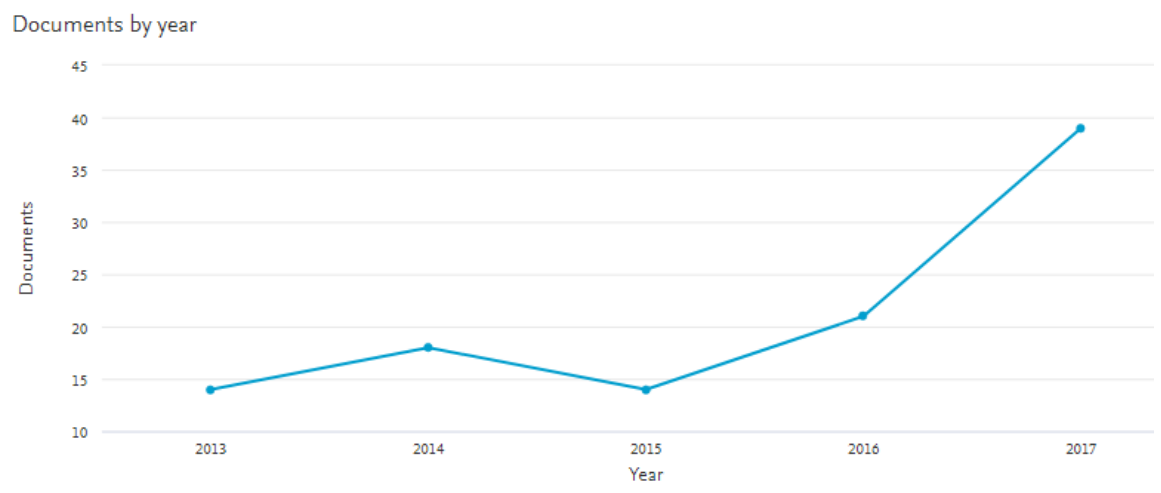

Рис. 1. Динаміка зростання кількості опублікованих статей у журналах, що індексуються у БД Scopus (за даними сайту Scopus)

У БД WoS за період 2013-2017 pp. НУК представлено 84 документами у 44 виданнях. Серед них 56 статей у журналах, 27 документів у матеріалах конференцій, 3 розділи книги та 1 огляд. 17 документів представлено у журналах відкритого доступу.

Найбільш активно автори публікували свої роботи у 2017 р. (34), 2015 р. (22) і 2016 p. (18), h-іndex складає 7, сумарна кількість цитувань 270.

Географія видань: США - 13 (29,5\%), Україна - $12(27,5 \%)$, Польща $-4(9,1 \%)$, РФ - 4 (9\%), Англія, Нідерланди, Хорватія по 2 (4,5\%). Німеччина, Молдова, Індія, Австрія, Швейцарія, РФ, Румунія по 1 (2,3\%).

Українські видання у БД $\mathrm{WoS}$ представлено 5 журналами та 7 матеріалами конференцій.

У БД WoS статті у журналах найбільш активно публікувалися у 2017 р. (26), 2016 р. (10), 2015 р. (16) (рис. 3).

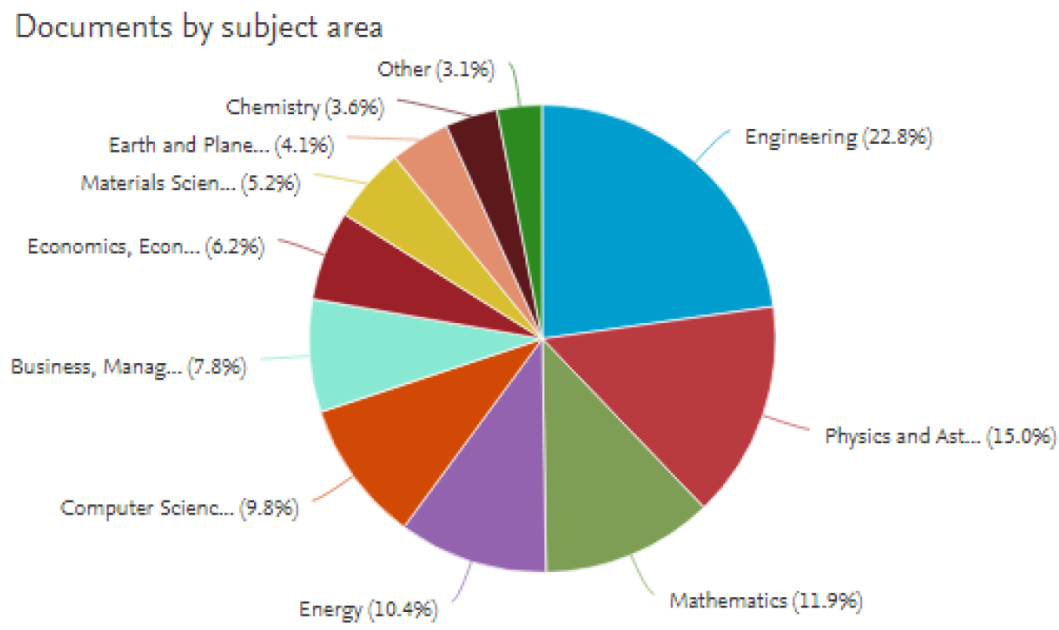

Рис. 2. Діаграма розподілу статей, надрукованих у журналах, що індексуються у БД Scopus за основними галузями знань (за даними сайту Scopus) 


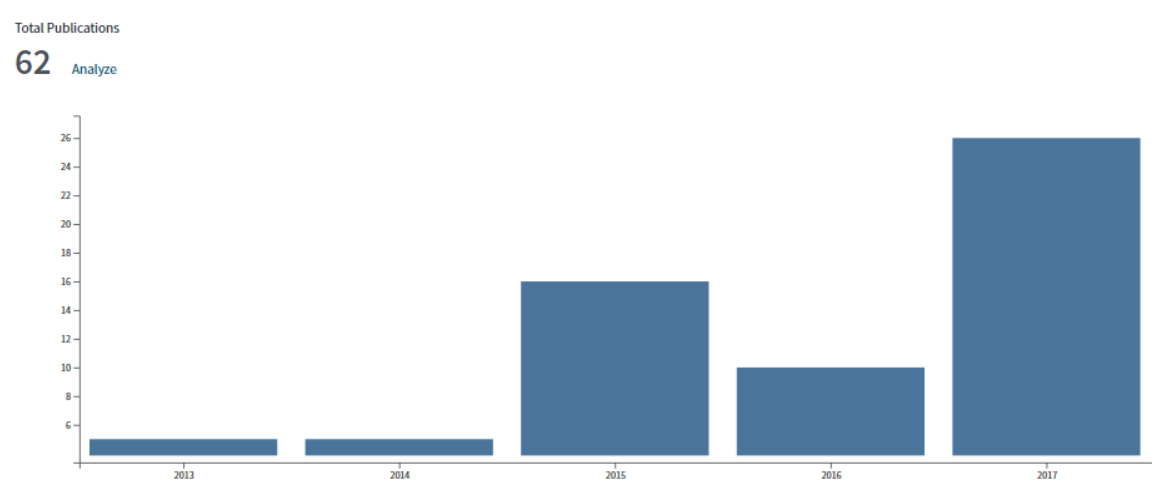

Рис. 3. Динаміка зростання кількості опублікованих статей у журналах, що індексуються у БД WoS (за даними сайту WoS)

Основні галузі знань, за якими було надруковано найбільше статей представлено на рис. 4: Physics fluids plasmas (14), Engineering electrical electronic (7), Engineering marine (6), Energy fuels (5), Chemistry physical (4).

Серед авторів найбільш активними були: Ushcats, M.V. (10), Serbin, S.I. (10), Korol, Y.M. (5), Moonesun, M. (5), Goncharova, N.A. (4), Washchilenko, N.V. (4), Bondarenko O.V. (3).

У БД WoS найбільш цитовані статті надруковано у журналах: Journal of Chemical Physics (20); Physical Review E (15); IEEE Transactions on Plasma Science (Том: 41, вип. 12) (14); Journal of chemical physics (13); IEEE Transactions on Plasma Science (Том: 42, вип. 12) (12).

Аналіз матеріалів конференцій, у яких публікувались автори-НПП, за даними БД Scopus у 2013-2017 pр. свідчить, що документи у матеріалах конференцій найбільш активно публікувалися у 2017 р. (15), 2016 р. (6), 2015 р. (7). Основні галузі знань, за якими було надруковано найбільше документів: Computer Science (29), Engineering (18), Decision Sciences (10), Mathematics (10), Energy (8), Earth and Planetary Sciences (5), Materials Science (5).

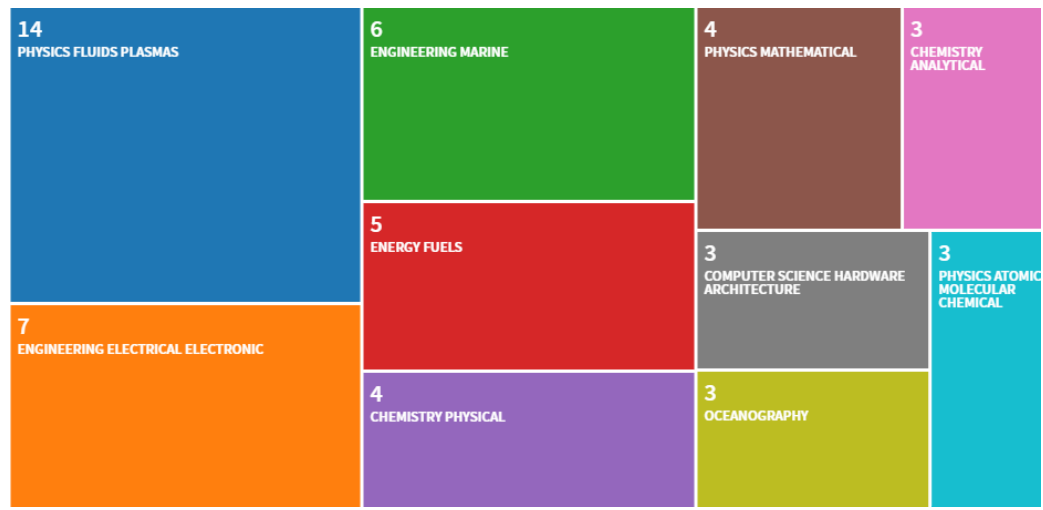

Рис. 4. Діаграма розподілу статей, надрукованих у журналах, що індексуються у БД $\mathrm{WoS}$ за основними галузями знань (за даними сайту $\mathrm{WoS}$ ) 
Серед авторів найбільш активними були: Kondratenko, Y.P. (13), Gerasin, O. (8), Kozlov, O.V. (8), Topalov, A. (8), Grigorian, T.G. (4), Koshkin, K.V. (4), Korobko, O. (3).

У БД WoS документи у матеріалах конференцій найбільш активно публікувалися у 2017 р. (13), 2016 р. (8), 2015 р. (6).

Основні галузі знань, за якими було надруковано найбільше робіт: Engineering electrical electronic (16), Computer science theory methods (14), Computer science artificial intelligence (7), Computer science software engineering (5).

Серед авторів найбільш активними були: Kozlov, O.V. (7), Kondratenko, Y.P. (6), Gerasin, O. (5), Topalov, A. (5), Grigorian, T.G. (4), Koshkin, K.V. (4), Korobko, O. (3).

У БД Scopus найбільш цитовані документи надруковано у наступних матеріалах конференцій: Proceedings of the 2013 IEEE 7th International Conference on Intelligent Data Acquisition and Advanced Computing Systems, IDAACS 2013, Volume 1, 2013 (13), Proceedings of the 2013 IEEE 7th International Conference on Intelligent Data Acquisition and Advanced Computing Systems, IDAACS 2013, Volume 2, 2013 (12), Studies in Fuzziness and Soft Computing, Volume 312, 2014 (8).

Серед видань, в яких найбільш активно публікувалися автори НУК, наступні: Easterneuropean Journal Of Enterprise Technologies (12); Actual Problems Of Economics (11); IEEE Transactions On Plasma Science (10); Technical Electrodynamics (7).

У БД WoS найбільш цитовані документи надруковано у матеріалах конференцій: 2015 IEEE 8th International Conference on Intelligent Data Acquisition and Advanced Computing Systems: Technology and Applications (IDAACS), vols 1-2 (6), 1st IEEE International Conference on Data Stream Mining and Processing (DSMP) (4).

Серед видань, в яких найбільш активно публікувалися автори НУК, наступні: IEEE Transactions On Plasma Science (10); Electrical Engineering Electromechanics (6); Physical Review E (4); Problemele Energeticii Regionale (4).

Найбільш впливові видання в окремій галузі науки - це видання 3 найбільшим цитуванням та імпакт-фактором. Імпакт-фактор журналу часто використовується в якості основного параметра, за допомогою якого порівнюють наукові результати окремих авторів і інститутів [16].

Проаналізовано найбільш впливові видання, у яких публікувалися автори-НПП НУК, за даними БД Scopus у 2013-2017 рр. за квартилем. 344 журналів, у яких публікувалися автори-НПП НУК, 2 видання (4,5\%) входять до Q1, $2(4,5 \%)$ - до Q1-2, $6(13,6 \%)$ - до Q2, $3(6,8 \%)$ - до $\mathrm{Q} 2-3,1(2,3 \%)$ - до Q 2-3-4, $14(31,8 \%)$ - до Q3, $4(9,1 \%)$ - до Q3-4, $9(20,5 \%)$ - до Q4 та 3 видання $(6,8 \%)$ не входять до жодного квартиля.

З 14 матеріалів конференцій, у яких публікувалися автори-НПП НУК, $2(14,2 \%)$ видання потрапили у квартилі, $1(7,1 \%)$ у Q3, $1(7,1 \%)$ у Q4. Нажаль, українські конференції не увійшли до жодного квартиля.

Проаналізовано найбільш впливові видання, у яких публікувалися автори-НПП НУК, за даними БД WoS у 2013-2017 pp., за квартилем. 344 видань, у яких публікувалися автори-НПП НУК, тільки $15(34,1 \%)$ потрапили до відповідного квартиля: 1 видання $(2,3 \%)$ входить до Q1-2, 
$2(4,5 \%)$ - до Q2, 1 (2,3\%) - до Q2-1, 3 (6,8\%) - до Q3, 8 (18,2\%) - до Q4, та 29 видань $(65,9 \%)$ не входять до жодного квартиля. Матеріали конференцій, у яких публікувалися автори-ННП НУК, не потрапили до жодного квартиля.

Найбільш впливові украӥнсъкі видання, у яких надруковані статті авторів-ННП НУК, за даними БД Scopus у 2013-2017 рр., за квартилем представлено у таблиці 4.

Таблиця 4. Найбільш впливові українські видання, у яких публікувалися автори-ННП НУК за даними БД Scopus у 2013-2017 рр., за квартилем

\begin{tabular}{|c|c|c|c|c|c|c|c|c|}
\hline № & $\begin{array}{c}\text { Квар- } \\
\text { тиль }\end{array}$ & $\begin{array}{c}\text { H- } \\
\text { index }\end{array}$ & Назва видання & $\begin{array}{l}\text { Кіль- } \\
\text { кість } \\
\text { доку- } \\
\text { ментів }\end{array}$ & $\begin{array}{c}\text { Cite } \\
\text { Score } \\
2016\end{array}$ & $\begin{array}{l}\text { SJR } \\
2016\end{array}$ & $\begin{array}{r}\text { SNIP } \\
2016\end{array}$ & Галузь знань \\
\hline 1 & Q3 & 8 & $\begin{array}{c}\text { Technical } \\
\text { Electrodynami- } \\
\text { cs }\end{array}$ & 7 & 0.38 & 0.187 & 0.837 & $\begin{array}{c}\text { Energy } \\
\text { Engineering }\end{array}$ \\
\hline 2 & Q3 & 10 & $\begin{array}{c}\text { Journal Of } \\
\text { Nano And } \\
\text { Electronic } \\
\text { Physics }\end{array}$ & 5 & 0.50 & 0.238 & 0.513 & $\begin{array}{l}\text { Materials } \\
\text { Science } \\
\text { Physics and } \\
\text { Astronomy }\end{array}$ \\
\hline 3 & Q3 & 5 & $\begin{array}{c}\text { Naukovyi } \\
\text { Visnyk } \\
\text { Natsionalnoho } \\
\text { Hirnychoho } \\
\text { Universytetu }\end{array}$ & 4 & 0.20 & 0.193 & 0.602 & Engineering \\
\hline 4 & Q3 & 6 & $\begin{array}{c}\text { Chemistry And } \\
\text { Chemical } \\
\text { Technology } \\
\end{array}$ & 1 & 0.32 & 0.235 & 0.242 & $\begin{array}{c}\text { Chemical } \\
\text { Engineering }\end{array}$ \\
\hline 5 & Q3 & 14 & $\begin{array}{c}\text { Ukrainian } \\
\text { Mathematical } \\
\text { Journal }\end{array}$ & 1 & 0.20 & 0.310 & 0.554 & Mathematics \\
\hline 6 & Q3-4 & 3 & $\begin{array}{c}\text { Easterneuropean } \\
\text { Journal Of } \\
\text { Enterprise } \\
\text { Technologies } \\
\end{array}$ & 12 & 0.09 & 0.187 & 0.043 & Engineering \\
\hline 7 & Q3-4 & 10 & $\begin{array}{c}\text { Metallofizika I } \\
\text { Noveishie } \\
\text { Tekhnologii } \\
\end{array}$ & 1 & 0.23 & 0.222 & 0.413 & $\begin{array}{l}\text { Materials } \\
\text { Science }\end{array}$ \\
\hline 8 & Q3-4 & 12 & $\begin{array}{l}\text { Problems and } \\
\text { Perspectives In } \\
\text { Management }\end{array}$ & 1 & 0.25 & 0.145 & 0.318 & $\begin{array}{c}\text { Business, } \\
\text { Management } \\
\text { and } \\
\text { Accounting }\end{array}$ \\
\hline 9 & Q4 & 8 & $\begin{array}{c}\text { Actual } \\
\text { Problems Of } \\
\text { Economics }\end{array}$ & 11 & $\begin{array}{l}\text { Cite } \\
\text { Score } \\
2015 \\
0.06\end{array}$ & 0.138 & 0.180 & $\begin{array}{l}\text { Economics, } \\
\text { Econometrics } \\
\text { and Finance }\end{array}$ \\
\hline 10 & Q4 & 11 & $\begin{array}{c}\text { Ukrainian } \\
\text { Journal Of } \\
\text { Physics } \\
\end{array}$ & 4 & 0.33 & 0.191 & 0.384 & $\begin{array}{c}\text { Physics and } \\
\text { Astronom }\end{array}$ \\
\hline 11 & - & - & $\begin{array}{l}\text { International } \\
\text { Journal Of } \\
\text { Computing } \\
\end{array}$ & 1 & - & - & - & $\begin{array}{l}\text { Computer } \\
\text { Science }\end{array}$ \\
\hline
\end{tabular}


З 11 українських журналів, що індексуються у БД Scopus, 5 видань (45,5\%) входять до Q3, 3 видання $(27,3 \%)$ - до Q3-4, 2 видання $(18,2 \%)-$ до Q4.

В українських журналах, що індексуються у БД Scopus, за 20132017 рр. надруковано 48 статей авторів-ННП НУК, з них 18 статей $(37,5 \%)$ у журналах Q3, 14 статей $(29,2 \%)$ у виданнях Q3-4, 15 статей $(31,3 \%)$ у виданнях Q4.

10 з 11 українських журналів, що індексуються у БД Scopus, i, в яких публікувалися автори НУК протягом 2013-2017 рр., входять до «Переліка наукових фахових видань України, в яких можуть публікуватися результати дисертаційних робіт на здобуття наукових ступенів доктора і кандидата наук», з них 2 видання не отримали перереєстрацію.

Найбільш впливовим українським виданням, у якому надруковано одну статтю авторів-НПП НУК, у БД WoS у 2013-2017 pp. є журнал Ukrainian Mathematical Journal, який входить до Q4. Він також входить до «Переліка наукових фахових видань України, в яких можуть публікуватися результати дисертаційних робіт на здобуття наукових ступенів доктора і кандидата наук».

Видання, в яких опубліковані роботи НПП НУК, які отримали найбільшу кількість посилань, представлені в таблиці 5 .

Таблиця 5. Видання-лідери, в яких опубліковані роботи вчених НУК у 2013-2017 рр., що отримали найбільшу кількість цитувань

\begin{tabular}{|c|c|c|c|c|c|c|c|}
\hline № & Видання & $\begin{array}{l}\text { БД, у якій } \\
\text { індексується }\end{array}$ & $\begin{array}{c}\text { Кількість } \\
\text { цитувань } \\
\text { на публі- } \\
\text { кації }\end{array}$ & $\begin{array}{c}\text { Періо- } \\
\text { дич- } \\
\text { ність } \\
\text { видання }\end{array}$ & ID & $\begin{array}{c}\text { H- } \\
\text { index }\end{array}$ & $\begin{array}{c}\text { Квар- } \\
\text { тиль }\end{array}$ \\
\hline 1 & $\begin{array}{l}\text { IEEE Transactions On } \\
\text { Plasma Science }\end{array}$ & $\begin{array}{c}\text { БД Scopus } \\
\text { БД WoS }\end{array}$ & 106 & 12 & 1,052 & 88 & Q2-3 \\
\hline 2 & $\begin{array}{l}\text { Journal Of Chemical } \\
\text { Physics }\end{array}$ & $\begin{array}{l}\text { БД Scopus } \\
\text { БД Wos }\end{array}$ & 71 & 2 & 2.965 & 286 & Q1 \\
\hline 3 & Physical Review E & $\begin{array}{l}\text { БД Scopus } \\
\text { БД WoS }\end{array}$ & 43 & 12 & 2,366 & 193 & Q1-2 \\
\hline 4 & Education Training & $\begin{array}{c}\text { БД Scopus } \\
\text { БД Wos }\end{array}$ & 27 & 9 & - & - & - \\
\hline 5 & $\begin{array}{l}\text { Proceedings Of The } 2013 \\
\text { IEEE 7th International } \\
\text { Conference On Intelligent } \\
\text { Data Acquisition And } \\
\text { Advanced Computing } \\
\text { Systems Idaacs } 2013 \\
\text { Conference Proceedin } \\
\end{array}$ & БД Scopus & 26 & 1 & - & - & - \\
\hline 6 & $\begin{array}{l}\text { Ukrainian Journal Of } \\
\text { Physics }\end{array}$ & $\begin{array}{c}\text { БД Scopus } \\
\text { БД Wos }\end{array}$ & 23 & 12 & - & 11 & Q4 \\
\hline 7 & $\begin{array}{l}\text { Proceedings Of The } 2015 \\
\text { IEEE 8th International } \\
\text { Conference On Intelligent } \\
\text { Data Acquisition And } \\
\text { Advanced Computing } \\
\text { Systems Technology And } \\
\text { Applications Idaacs } 2015 \\
\text { Conference Proceeding }\end{array}$ & $\begin{array}{c}\text { БД Scopus } \\
\text { БД Wos }\end{array}$ & 23 & 1 & - & - & - \\
\hline
\end{tabular}


3 таблиці 5 ми бачимо, що лідерами в даному рейтингу є, насамперед, видання 3 високим рейтингом і імпакт-фактором: 1 журнал, що увійшов до Q1; 1 - до Q1-2; 1 - до Q2-3; 1 - до Q4.

Слід зазначити, що віднесення журналів до Q1-Q4 - не просто відповідність еталону; це міра цитованості, а отже, міра цінності журналів. 3 наведених даних видно, що більшість видань, в яких публікуються авториНПП НУК, відносяться до Q3 та Q4, що також є показником високої цінності журналів.

Грунтуючись на цих даних, можна зробити висновок, що публікація наукових робіт у виданнях з високим рейтингом і великою періодичністю, підвищує шанси на високу цитованість, починаючи з моменту виходу їх у світ.

Згідно з проведеним аналізом видань можна зробити висновок, що основну частину опублікованих документів в БД Scopus i WoS становлять наукові статті (Article) в провідних наукових журналах - 180 у БД Scopus i 108 у БД WoS, за період 2013-2017 pp. 105 і 58 відповідно. Починаючи з 2015 р. активно зростає кількість публікацій у матеріалах конференцій (Conference Paper (Proceedings Paper) 62 у БД Scopus i 37 у БД WoS, за період 2013-2017 pp. 33 і 27 відповідно. Виявлено найбільш впливові видання та видання-лідери, в яких опубліковані роботи вчених НУК у 20132017 рр., що отримали найбільшу кількість цитувань, а також найбільш активні автори-НПП НУК.

В таблицях 6 і 7 проведено кількісну оцінку рівня наукових напрямів за період 2013-2017 pp. в наукометричних БД Scopus та WoS. Проаналізувавши розподіл публікацій за предметними галузями знань, ми бачимо, що університет представлений не однаково в усіх напрямках. На нашу думку це цілком виправдано. Існують напрямки, які формують обличчя університету, можливість впізнати його зовні. Це пов'язано з традиційно сильними напрямками наукових досліджень нашого університету, який є єдиним в Україні з підготовки фахівців з суднобудування. В ході дослідження було з'ясовано, що в БД Scopus та WoS більша частка публікацій відноситься до досліджень в галузі технічних наук (Engnering), що відповідає напрямку нашого університету. 3 таблиць 6, 7 ми бачимо, що з 2015 року цей напрям став пріоритетним та склав 44,7\% (Scopus), 34,5\% (WoS) від загальної кількісті публікацій в кожній БД за 5 років. В своїх працях вчені НУК висвітлюють проблеми модернізації суднобудівної промисловості, а саме: судноплавства, портів, судноремонту, суміжних галузей (електротехнічної та кабельної промисловості, машинобудування, електроніки, тощо), від яких залежить її розвиток. Значними показниками є також публікації 3 комп'ютерних наук (Computer science) 35.5 \% (Scopus), $21.429 \%$ (WoS), технічним напрямком яких, здебільшого, $є$ управління проектами, які також спрямовані на вирішення проблем суднобудування. Стабільну публікаційну активність проявляють автори напрямку досліджень з фізики (Physics), публікації яких складають 21,3\% (Scopus), 25,0\% (WoS).

На основі наукометричних засобів визначено галузі науки, котрі доцільно запропонувати як пріоритети інноваційного розвитку національної економіки України [17]. 
Таблиця 6. Аналіз публікацій науково-педагогічних працівників HУК за галузями знань БД Scopus

\begin{tabular}{|c|c|c|c|c|c|c|c|c|c|c|c|c|}
\hline \multirow{2}{*}{$\begin{array}{c}\text { Галузь } \\
\text { знань }\end{array}$} & \multicolumn{2}{|c|}{2013} & \multicolumn{2}{|c|}{2014} & \multicolumn{2}{|c|}{2015} & \multicolumn{2}{|c|}{2016} & \multicolumn{2}{|c|}{2017} & \multirow[b]{2}{*}{ 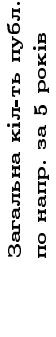 } & \multirow[b]{2}{*}{ 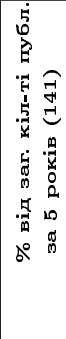 } \\
\hline & $\begin{array}{l}5 \\
0 \\
0 \\
0 \\
0 \\
0 \\
5 \\
5 \\
5 \\
5\end{array}$ & 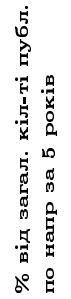 & 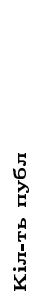 & 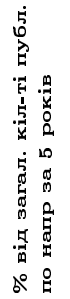 & $\begin{array}{l}5 \\
0 \\
0 \\
0 \\
0 \\
5 \\
5 \\
5\end{array}$ & 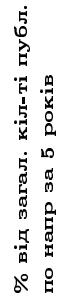 & $\begin{array}{r}5 \\
0 \\
0 \\
0 \\
0 \\
5 \\
5 \\
5 \\
5\end{array}$ & 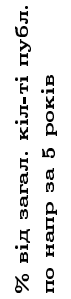 & $\begin{array}{l}5 \\
0 \\
0 \\
0 \\
5 \\
5 \\
5\end{array}$ & 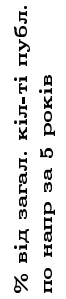 & & \\
\hline Engineering & 3 & 16,7 & 5 & 26,3 & 11 & 52,4 & 15 & 53,6 & 29 & 52,7 & 63 & 44,7 \\
\hline $\begin{array}{l}\text { Computer } \\
\text { Science }\end{array}$ & 5 & 27,8 & 1 & 5,3 & 6 & 28,6 & 10 & 35,7 & 28 & 50,9 & 50 & 35,5 \\
\hline Mathematics & 2 & 11,1 & 2 & 10,5 & 1 & 4,8 & 7 & 25,0 & 23 & 41,8 & 35 & 24,8 \\
\hline $\begin{array}{l}\text { Physics and } \\
\text { Astronomy }\end{array}$ & 6 & 33,3 & 7 & 36,8 & 7 & 33,3 & 5 & 17,9 & 5 & 9,1 & 30 & 21,3 \\
\hline Energy & - & - & 1 & 5,3 & 1 & 4,8 & 11 & 39,3 & 15 & 27,3 & 28 & 19,9 \\
\hline $\begin{array}{l}\text { Business, } \\
\text { Management } \\
\text { and }\end{array}$ & 1 & 5,6 & - & - & - & - & 4 & 14,3 & 14 & 25,5 & 19 & 13,5 \\
\hline $\begin{array}{l}\text { Materials } \\
\text { Science }\end{array}$ & 3 & 16,7 & 3 & 15,8 & 2 & 9,5 & 1 & 3,6 & 7 & 12,7 & 16 & 11,3 \\
\hline $\begin{array}{l}\text { Economics, } \\
\text { Econometrics } \\
\text { an }\end{array}$ & 2 & 11,1 & 4 & 21,1 & 4 & 19,0 & 1 & 3,6 & 3 & 5,5 & 14 & 9,9 \\
\hline $\begin{array}{l}\text { Earth and } \\
\text { Planetary } \\
\text { Sciences }\end{array}$ & 1 & 5,6 & - & - & 1 & 4,8 & 4 & 14,3 & 7 & 12,7 & 13 & 9,2 \\
\hline $\begin{array}{l}\text { Decision } \\
\text { Sciences }\end{array}$ & - & - & - & - & 5 & 23,8 & 1 & 3,6 & 6 & 10,9 & 12 & 8,5 \\
\hline Chemistry & 1 & 5,6 & 2 & 10,5 & - & - & 1 & 3,6 & 4 & 7,3 & 8 & $\begin{array}{l}\text { Інш } \\
11,3\end{array}$ \\
\hline $\begin{array}{l}\text { Social } \\
\text { Sciences }\end{array}$ & 1 & 5,6 & - & - & - & - & - & - & 3 & 5,5 & 4 & \\
\hline $\begin{array}{l}\text { Chemical } \\
\text { Engineering }\end{array}$ & - & - & - & - & - & - & - & - & 2 & 3,6 & 2 & \\
\hline $\begin{array}{l}\text { Environmental } \\
\text { Science }\end{array}$ & - & - & - & - & - & - & - & - & 1 & 1,8 & 1 & \\
\hline $\begin{array}{l}\text { Health } \\
\text { Professions }\end{array}$ & - & - & - & - & - & - & - & - & 1 & 1,8 & 1 & \\
\hline
\end{tabular}

Аналіз публікаційної активності авторів-НПП НУК імені адмірала Макарова у галузі знань Engineering представлено у таблиці 8.

У загальному профілі НУК у БД Scopus (60007756) представлено 196 авторів (НПП НУК з співавторами), з них авторів-НПП НУК- 93. За галуззю знань Engineering всього працюють 76 авторів, що складає $82 \%$ від загального числа авторів-НПП НУК, у 43 (57\%) з них є праці за період 2013-2017 pр. 3250 документів, що входять до наукометричної БД Scopus, загальна кількість публікацій з Engineering - 136, що складає 54,4 \%. Зі 141 документа, опублікованого у період 2013-2017 pp., 63 документи з Engineering, що складає $45 \%$. 3 загальної кількості цитувань документів у БД Scopus (590) кількість цитувань з Engineering - 176 (30\%). Кількість цитувань за 2013-2017 pp. - 465, з них кількість цитувань з Engineering 123, що складає $26,5 \%$. 
Таблиця 7. Аналіз публікацій науково-педагогічних працівників НУК за галузями знань БД Web of Science

\begin{tabular}{|c|c|c|c|c|c|c|c|c|c|c|c|c|}
\hline \multirow{2}{*}{$\begin{array}{c}\text { Галузь } \\
\text { знань }\end{array}$} & \multicolumn{2}{|c|}{2013} & \multicolumn{2}{|c|}{2014} & \multicolumn{2}{|c|}{2015} & \multicolumn{2}{|c|}{2016} & \multicolumn{2}{|c|}{2017} & \multirow[b]{2}{*}{ 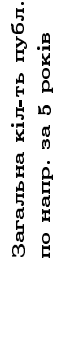 } & \multirow[b]{2}{*}{ 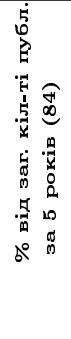 } \\
\hline & $\begin{array}{l}5 \\
0 \\
0 \\
0 \\
0 \\
1 \\
5 \\
5 \\
5\end{array}$ & 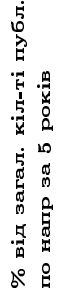 & $\begin{array}{l}5 \\
0 \\
0 \\
0 \\
5 \\
5 \\
5 \\
5 \\
5\end{array}$ & 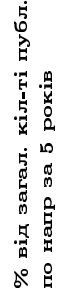 & 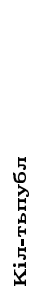 & 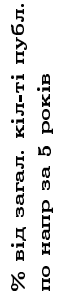 & 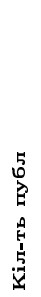 & 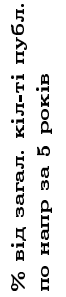 & 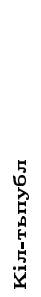 & 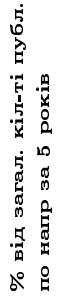 & & \\
\hline Engineering & 1 & 3,5 & - & - & 10 & 34,5 & 6 & 20,7 & 12 & 41,4 & 29 & 34,5 \\
\hline Physics & 3 & 14,3 & 4 & 19,1 & 5 & 23,8 & 5 & 23,8 & 4 & 19,1 & 21 & 25 \\
\hline $\begin{array}{l}\text { Computer } \\
\text { Science }\end{array}$ & - & - & - & - & 6 & 33,3 & 3 & 16,7 & 9 & 50 & 18 & 21,4 \\
\hline Energy Fuels & - & - & - & - & 2 & 25 & 4 & 50 & 2 & 25 & 8 & 9,5 \\
\hline Chemistry & 1 & 14,3 & 2 & 28,6 & - & - & 1 & 14,3 & 3 & 42,9 & 7 & 8,3 \\
\hline $\begin{array}{l}\text { Automation } \\
\text { Control } \\
\text { Systems }\end{array}$ & 1 & 16,7 & - & - & 1 & 16,7 & 1 & 16,7 & 3 & 50 & 6 & 7,1 \\
\hline Oceanography & - & - & - & - & - & - & 3 & 100 & & - & 3 & 3,6 \\
\hline $\begin{array}{l}\text { Science } \\
\text { Technology } \\
\text { Other Topics }\end{array}$ & - & - & - & - & 1 & 33 & - & - & 2 & 66,7 & 3 & 3,6 \\
\hline Transportation & . & - & - & - & 1 & 33,3 & - & - & 2 & 66,7 & 3 & 3,6 \\
\hline Mathematics & - & - & 1 & 50 & - & - & - & - & 1 & 50 & 2 & 2,4 \\
\hline Electrochemistry & - & - & - & - & 1 & 100 & - & - & - & - & 1 & 1,2 \\
\hline $\begin{array}{l}\text { Materials } \\
\text { Science }\end{array}$ & - & - & - & - & - & - & - & - & 1 & 100 & 1 & 1,2 \\
\hline $\begin{array}{l}\text { Operations } \\
\text { Research } \\
\text { Management } \\
\text { Science }\end{array}$ & - & - & - & - & - & - & - & - & 1 & 100 & 1 & 1,2 \\
\hline Robotics & - & - & - & - & 1 & 100 & - & - & - & - & 1 & 1,2 \\
\hline Thermodynamic & - & - & - & - & 1 & 100 & - & - & - & - & 1 & 1,2 \\
\hline
\end{tabular}

Таблиця 8. Аналіз публікаційної активності авторів-НПП НУК у галузі знань Engineering

\begin{tabular}{|c|c|c|c|c|c|c|c|c|c|c|c|c|}
\hline \multirow{2}{*}{ вд } & \multicolumn{4}{|c|}{ Кількість авторів } & \multicolumn{4}{|c|}{ Кількість публікацій } & \multicolumn{4}{|c|}{ Кількість цитувань } \\
\hline & 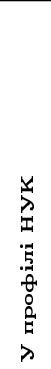 & 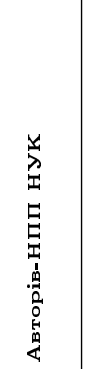 & 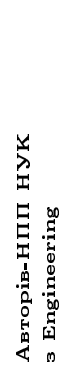 & 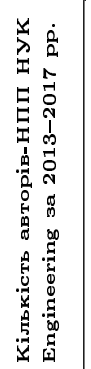 & 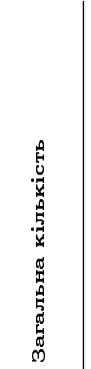 & 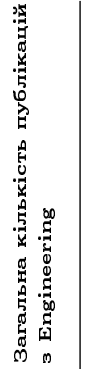 & 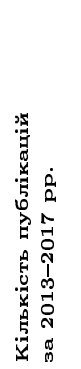 & 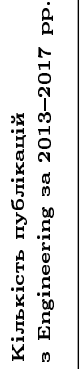 & 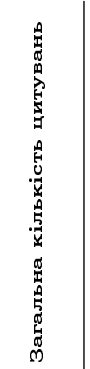 & 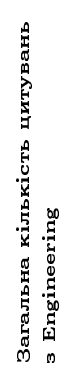 & 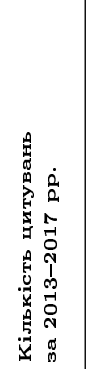 & 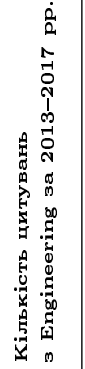 \\
\hline $\begin{array}{c}\text { БД } \\
\text { Scopus }\end{array}$ & 196 & $\begin{array}{c}93 \\
(100 \%)\end{array}$ & $\begin{array}{c}76 \\
(82 \%) \\
\end{array}$ & $\begin{array}{c}43 \\
(57 \%) \\
\end{array}$ & $\begin{array}{c}250 \\
(100 \%)\end{array}$ & $\begin{array}{c}136 \\
(54,4 \%)\end{array}$ & $\begin{array}{c}141 \\
(100 \%) \\
\end{array}$ & $\begin{array}{c}63 \\
(45 \%) \\
\end{array}$ & $\begin{array}{c}590 \\
(100 \%) \\
\end{array}$ & $\begin{array}{c}176 \\
(30 \%) \\
\end{array}$ & $\begin{array}{c}465 \\
(100 \%) \\
\end{array}$ & $\begin{array}{c}123 \\
(26,5 \% \\
\end{array}$ \\
\hline $\begin{array}{l}\text { БД } \\
\text { WoS }\end{array}$ & 246 & $\begin{array}{c}136 \\
(100 \%)\end{array}$ & $\begin{array}{c}94 \\
(69 \%)\end{array}$ & $\begin{array}{c}53 \\
(56,4 \%)\end{array}$ & $\begin{array}{c}144 \\
(100 \%)\end{array}$ & $\begin{array}{c}38 \\
(26,4 \%)\end{array}$ & $\begin{array}{c}84 \\
(100 \%)\end{array}$ & $\begin{array}{c}29 \\
(34,5 \%\end{array}$ & $\begin{array}{c}310 \\
(100 \%)\end{array}$ & $\begin{array}{c}19 \\
(6,1 \%)\end{array}$ & $\begin{array}{c}270 \\
(100 \%)\end{array}$ & $\begin{array}{c}11 \\
(4,1 \%)\end{array}$ \\
\hline
\end{tabular}


Продуктивність авторів-НПП НУК (середня кількість публікацій із розрахунку на 1 автора) у напрямку Engineering складає 1,8, а за період 2013-2017 pp. - 1,5.

У загальному профілі HУK у БД WoS представлено 246 авторів (НПП НУК з співавторами), з них авторів-НПП НУК - 136. За галуззю знань Engineering всього працюють 93 автори, що складає $69 \%$ від загального чиста авторів-НПП НУК, у 53 (56,4\%) з них є праці за період 2013-2017 pp. 3144 документів, що входять до наукометричної БД WoS, загальна кількість публікацій з Engineering - 38, що складає 26,4\%. 384 документів, опублікованих у період 2013-2017 pp., 29 документів з Engineering, що складає 34,5\%. 3 загальної кількості цитувань документів у БД WoS (310) - кількість цитувань з Engineering 19 (6,1\%). Кількість цитувань за 2013-2017 рр. - 270, з них кількість цитувань з Engineering - 11, що складає $4,1 \%$.

Продуктивність (середня кількість публікацій із розрахунку на 1 автора) авторів-НПП НУК у напрямку Engineering складає 0,4, а за період 2013-2017 pp. - 0,5.

Не зважаючи на те, що наукометричні показники індексів цитування відіграють важливу роль при оцінці наукової діяльності авторів, видань, установи в цілому, ми вважаємо, що вони не можуть бути єдиним критерієм якості і значущості вченого і інституції, в якій вони працюють. При проведенні оцінки наукової діяльності слід проводити комплексний аналіз даних, які можна застосувати для конкретної предметної області [18].

В рамках підготовки конкурсної роботи співробітниками Наукової бібліотеки НУК було проведено соціологічне дослідження щодо обізнаності та компетентності вчених НУК з наукометричних ресурсів, а саме БД Scopus та WoS.

За підсумками анкетування, у якому взяли участь 160 НПП НУК, можна зробити висновок, що $70 \%$ опитаних науковців використовують у роботі наукометричні ресурси, а саме БД Scopus та WoS, а основними перешкодами успішної діяльності та інтеграції до європейського науковоосвітнього простору університету вважають недостатнє фінансове стимулювання, труднощі при публікації у рейтингових виданнях та низьку мовну компетентність, яка не дозволяє без професійної допомоги перекладачів донести результати наукових досліджень до фахівців з інших країн.

Результати дослідження підтверджують досить високу ефективність дослідницької діяльності НУК. Вагомий внесок у покращення зазначеної ефективності здійснюють заохочення університетських журналів до світових інформаційних мереж та сприяння створенню «видимості» фахівців НУК та результатів їх досліджень у світових інформаційних мережах [11].

Проведений аналіз дозволив оцінити кількісні параметри публікаційної активності Національного університету кораблебудування імені адмірала Макарова і зробити наступні висновки:

1. У 2013-2017 рр. спостерігалася позитивна динаміка зростання кількості публікацій наукових співробітників НУК.

2. 32015 р. помітно зросла публікаційна активність авторів університету у наукометричних БД Scopus та WoS. Однією з причин ми вважаємо початок реалізації Постанови Кабінету Міністрів України від 
30 грудня 2015 р. № 1187 «Про затвердження Ліцензійних умов провадження освітньої діяльності закладів освіти». Інший важливий фактор - підвищення інформованості НПП про способи оцінки результативності їх праці, чому сприяють заходи щодо формування інформаційної культури, що проводяться НБ НУК.

3. Більша частина публікацій відноситься до досліджень з технічних наук (Engnering), комп'ютерних наук (Computer science), фізики (Physics). Це пов'язано з традиційно сильними напрямками наукових досліджень в університеті. Саме ці напрямки НУК позначені як пріоритетні, але розвиваються напрямки і в інших областях науки, і ми очікуємо, що тематична спрямованість публікацій буде розширюватися.

4. Організація і управління публікаційною активністю процес складний і багатоаспектний, вирішувати завдання, пов'язані з ростом результативності наукової діяльності, можна тільки на системному рівні [1]. Для повноти оцінки публікаційної активності установи необхідні методики, з вибірки та аналізу публікацій з БД Scopus i WoS, виконаних як по організації в цілому, так і по персоналіях окремих вчених, методика оцінки наукового потенціалу організації також потребує уточнення, розробки нових методів оцінки продуктивності дослідницької діяльності [19].

Крім цього необхідно запропонувати новий альтернативний підхід до питання фінансового стимулювання росту наукової продуктивності в університетах України, який би грунтувався на наукометричних показниках, але при цьому враховував особливості різних предметних галузей [20].

5. Завдяки проведеному дослідженню стало можливим визначити пріоритетні напрямки наукових розробок, а також виявити вчених наукових лідерів університету. Результати проведеного аналізу публікаційної активності НПП НУК ми вважаємо вкрай важливими. Вони можуть бути використані як інструмент для виявлення слабких сторін науково-дослідницької діяльності університету і пошуку шляхів iii удосконалення. Надалі ми вважаємо результати проведеного дослідження будуть застосовані при аналізі наукової та господарської діяльності Миколаївського регіону, а саме відродження суднобудівної галузі в Україні.

\section{Література}

[1] Еременко, Т. В. 2018. Индикаторы публикационной активности регионального научного сообщества: постановка проблемы. Научные $u$ технические библиотеки 1:43-50.

[2] Вялков, А. И. 2013. Оценка качества научно-исследовательской деятельности медицинской организации с помощью наукометрических показателей. Здравоохранение $P \Phi$ 3:3-5.

[3] Ellegaard, Ole, and Johan A. Wallin 2015. The bibliometric analysis of scholarly production: How great is the impact? Scientometrics, 105(3): 1809-1831, https://doi.org/10.1007/s11192-015-1645-z. 
[4] Гуськов, А. Е.2017. Стратегии повышения публикационной активности университетов Проекта 5-100. Научные и технические библиотежи 12:5-18.

[5] Кирвас, В. А. 2013. Наукометрическая оценка результатов исследовательской деятельности ученых и качества периодических научных изданий. Системи обробки інформації 8:5-15.

[6] Боргоякова, К. С. 2017. Методика определения цитируемости научных публикаций исследователя. Библиосфера 1:103-109, https://doi.org/ 10.20913/1815-3186-2017-1-103-109.

[7] Varin, Cristiano, Manuela Cattelan, and David Firth 2016. Statistical modelling of citation exchange between statistics journals. Journal of the Royal Statistical Society Series A (Statistics in Society) 179(1):1-63, https://doi.org/10.1111/rssa.12124.

[8] Nagarkar, Shubhada, Chaitanya Veer, and Rajendra Kumbhar 2015. Bibliometric Analysis of Papers Published by Faculty of Life Science Departments of Savitribai Phule Pune University during 1999-2013. DESIDOC Journal of Library $\&$ Information Technology. 35(5):368-375, https://doi. org/10.14429/djlit.35.5.8429.

[9] Mahalakshmi, G. S., G. Muthu Selvi, and S. Sendhilkumar 2017. A Bibliometric Analysis of Journal of Informetrics - A Decade Study. Second International Conference on Recent Trends and Challenges in Computational Models (ICRTCCM), (2017):222-227. https://doi.org/10.1109/ icrtccm.2017.22.

[10] Cancino, Christian A., José M. Merigó, and Freddy C. Coronado 2017. A bibliometric analysis of leading universities in innovation research. Journal of Innovation \& Knowledge 2(3):106-124. https://doi.org/10. 1016/j.jik.2017.03.006.

[11] Скалабан, А. В., И.В.Юрик и В. С. Лазарев. 2017. Библиометрическое исследование публикаций работников Белорусского национального технического университета с помощью баз данных Web of Science и Scopus и оценка эффективности их научной деятельности: 20112015 гг. Приборы и методы измерений 1(8): 81-92. https://doi.org/10. 21122/2220-9506-2017-8-1-81-92.

[12] Смолина, С. Г. 2013. Анализ публикационной активности и опыт организации мониторинга Южно-Уральского государственного университета. Библиосфера 2:82-87.

[13] Мохначева Ю. В. 2017. Цитируемость научных публикаций: особенности и закономерности. Научные и технические библиотеки 6:3-24.

[14] Польдин О.В., Н.Н. Матвеева, И.А. Стерлигов и М.М. Юдкевич. 2017. Публикационная активность вузов: эффект проекта «5-100». Вопросы образования 2:10-35.

[15] Нікітенко О. М. 2017. Оцінювання рейтингу науковців за відображеннями у наукометричних базах даних. Матеріали Інтернет-конференції: «Вимірювання в бібліотеках: оцінка ефективності та якості роботи». Харків, Червень 6-10.

[16] Колледж, Л. 2016. «Корзина метрик» - лучшее средство для оценки авторитета журнала. Научный редактор и издатель 1-4(1):25-31. https://doi.org/10.24069/2542-0267-2016-1-4-25-31. 
[17] Корецький, А. I. 2016. Наукометричні засоби у визначенні пріоритетів інноваційного розвитку національної економіки. Дис. канд. екон. наук, «Університет економіки та права "КРOK"». Київ.

[18] Газизова, Д. Г. 2017. Библиометрический анализ данных по отраслевой тематике: индекс качества и производительности. Научные u meхнические библиотеки 12:19-30.

[19] Шапошникова Т.Л., Д.А. Романов, Е.С. Киселева и Р. В. Терюха. 2015. Новые методы оценки продуктивности исследовательской деятельности. Ученые записки университета Лесгафта 3(121):184-186.

[20] Назаровець, Сергій. 2016. Квартильний підхід до проблеми стимулювання росту наукової продуктивності в університетах України. Бiбліотечний форум: історія, теорія і практика 2(4):10-12.

\section{References}

[1] Yeremenko, Tatiana, and Chris James. 2018. Indicators of regional scientific community publication activity. $S T L / N T B$ 1:43-50.

[2] Vyalkov, A. I., and E.A. Glukhova. 2013. The Evaluation of Quality of Research Activities of Medical Organization Using Scientometric Indicators. Zdravookhranenie Rossiyskoy Federatsii 3:3-5.

[3] Ellegaard, Ole, and Johan A. Wallin 2015. The bibliometric analysis of scholarly production: How great is the impact? Scientometrics 105(3): 1809-1831, https://doi.org/10.1007/s11192-015-1645-z.

[4] Guskov, Andrey, Denis Kosyakov, and Irina Selivanova. 2017. Strategies to Improve Publication Activities of the Universities Participating in Project 5-100. STL/NTB 12:5-18.

[5] Kirvas, V.A. 2013. Scientometric Evaluation of Results of Scholarly Research Activity and Quality of Periodical Scientific Publications. Information Processing Systems 8:5-15.

[6] Borgoyakova K.C. 2017. Methods to Determine Scientific Publications Citation of a Researcher. Bibliosphere 1:103-109. Accessed September 12, 2018, https://doi.org/10.20913/1815-3186-2017-1-103-109.

[7] Varin, Cristiano, Manuela Cattelan, and David Firth 2016. Statistical modelling of citation exchange between statistics journals. Journal of the Royal Statistical Society Series A (Statistics in Society) 179(1):1-63, https://doi.org/10.1111/rssa.12124.

[8] Nagarkar, Shubhada, Chaitanya Veer, and Rajendra Kumbhar 2015. Bibliometric Analysis of Papers Published by Faculty of Life Science Departments of Savitribai Phule Pune University during 1999-2013. DESIDOC Journal of Library $\&$ Information Technology. 35(5):368-375, https://doi. org/10.14429/djlit.35.5.8429.

[9] Mahalakshmi, G. S., G. Muthu Selvi, and S. Sendhilkumar 2017. A Bibliometric Analysis of Journal of Informetrics-A Decade Study. Second International Conference on Recent Trends and Challenges in Computational Models (ICRTCCM), (2017):222-227, https://doi.org/10.1109/ icrtccm.2017.22. 
[10] Cancino, Christian A., José M. Merigó, and Freddy C. Coronado 2017. A bibliometric analysis of leading universities in innovation research. Journal of Innovation \& Knowledge 2(3):106-124, https://doi.org/10. 1016/j.jik.2017.03.006.

[11] Skalaban, A., I. Yurik, and V. Lazarev. 2017. Bibliometric Study of Publications of Employees of the Belarusian National Technical University Fulfilled With the Use of the Web of Science and Scopus Databases and Evaluation of the Efficiency of Their Research Activities. Devices and Methods of Measurements 8(1): 81-92. https://doi.org/10.21122/22209506-2017-8-1-81-92.

[12] Smolina, S. G. 2013. Assessment of the Publication Activity and Monitoring Experience of the South Ural State University. Bibliosphere 2:82-87.

[13] Mokhnacheva, Yulia. 2017. Citation of scientific publications: Features and patterns. STL/NTB 6:3-24.

[14] Poldin, Oleg, Nataliya Matveeva, Ivan Sterligov, and Maria Yudkevich. 2017. Publication Activities of Russian Universities: The Effects of Project 5-100. Voprosy obrazovania / Educational Studies Moscow 2:10-35.

[15] Nikitenko, A. N., and N.V. Plechenko. 2017. Evaluation of the Researchers' Rankings Based on Data From the Scientometric Databases. In Proceedings of the Web-Conference on Assessment in Libraries: Work efficiency and quality evaluation, Kharkov National University of Radio Electronics, Kharkov, November 6-10.

[16] Colledge, Lisa. 2016. A "Basket of Metrics"- the Best Support for Understanding Journal Merit2. Science Editor and Publisher 1-4(1):25-31. Accessed September 12, 2018. https://doi.org/10.24069/2542-0267-20161-4-25-31.

[17] Koretskyi, A.I. 2016. Scientometric instruments in identifying priorities innovative development of national economy. The thesis for the degree of a Candidate of Economic Sciences, Higher Educational Establishment «University of Economy and Law «KROK», Kyiv.

[18] Gazizova, Darina. 2017. Discipline-specific Bibliometric Analysis: Quality and Performance Indexes. STL/NTB 12: 19-30.

[19] Shaposhnikova, Tatyana, Dmitry Romanov, Elena Kiseleva, and Roman Teryukha. 2015. New methods for the investigative activity efficiency evaluation. Ushenye zapiski universiteta imevi P.F. Lesgafta 3(121): 184186.

[20] Nazarovets, Serhii. 2016. Quartile approach to stimulating the growth of scientific productivity in Ukraine universities. Bibliotechnyi forum: istoriia, teoriia i praktyka 2(4):10-12. 